\title{
Upaya Pengendalian Faktor Resiko PTM (Penyakit Tidak Menular)
}

\author{
Purwati, Alfi Noviyana, Dea Roudhotul \\ E mail: watix_1006@yahoo.com, alfinovi13@gmail.com,dhearoudhatul07@gmail.com \\ Kebidanan DIII, Fikes Universitas Muhammadiyah Purwokerto, Indonesia \\ J1. Sorpardjo Roestam Km 7 Sokaraja Banyumas \\ Telp/fax (0281) 6844252, 68344253
}

\begin{abstract}
Abstrak
Permasalahan secara umum di kabupaten banyumas terkait denga Penyakit tidak menulatr adalah: tidak adanya penyuluhan kesehatan, kurangnya pengetahuan dan keterampilan kader, kurangnya dukungan masyarakat, dan rendahnya kunjungan lansia/ kelompok sasaran. Posbindu di desa Pamijen dilaksanakan dengan terintegrasi kegiatan posyandu balita dimana kegiatannya masih terbatas dengan hanya pemantauan tekanan darah dan pengobatan penyakit ringan, sedangkan kegiatan penyuluhan dari petugas kesehatan masih jarang dilaksanakan. Kondisi tersebut yang menjadikan ibu-ibu ranting asyiyah Pamijen belum tergerak untuk mengikuti Posbindu. Selain itu kondisi dari kader Posbindu yang belum siap dan belum terampil. Metode penyelesaian masalah yang dilaksanakan pada pengabdian masyarakat ini adalah dengan memberikan KIE (Komunikasi, Informasi dan Edukasi) berupa materi tentang Penyakit Tidak Menular (PTM) dan faktor resiko dan upaya pengendalian faktor resiko PTM. Kegiatan PTM di desa Pamijen melibatkan organisasi Aisyiyah sebagai organisasi yang aktif dalam masyarakat untuk menindaklanjuti program Kemenkes sehingga program dapat berjalan sesuai yang diharapkan. Tindak lanjut dari kegiatan ini dilaksanakan pada kegiatan Posbindu di desa Pamijen yang dilaksankan rutin setiap 1 bulan sekali. Ada peningkatan pengetahuan tentang PTM pada kader Aisyiyah desa Pamijen sehingga Kader Aisyiyah dapat mengenali PTM pada dirinya sendiri dan mengedukasi masyarakat untuk mengenali PTM.
\end{abstract}

Kata Kunci: PTM; posbindu.

\begin{abstract}
Problems in general in Banyumas district related to non-regular diseases are: lack of health education, lack of knowledge and skills of cadres, lack of community support, and low visits by elderly / target groups. Posbindu in Pamijen village is implemented with integrated posyandu activities for toddlers where the activities are still limited to monitoring blood pressure and treating minor illnesses, while counseling activities from health workers are rarely carried out. This condition has made the mothers of the Asyiyah Pamijen branch not yet moved to join Posbindu. Apart from that, the Posbindu cadres were not ready and skilled. The method of solving problems implemented in this community service is by providing IEC (Communication, Information and Education) in the form of material about Non-Communicable Diseases (PTM) and risk factors and efforts to control PTM risk factors. PTM activities in Pamijen village involve Aisyiyah's organization as an organization that is active in the community to follow up on the Ministry of Health program so that the program can run as expected. The follow-up of this activity is carried out at the Posbindu activity in Pamijen village which is carried out routinely every 1 month. There is an increase in knowledge about PTM in Aisyiyah cadres in Pamijen village so that Aisyiyah cadres can recognize PTM on their own and educate the public to recognize PTM.
\end{abstract}

Keyword: PTM; posbindu. 


\section{Pendahuluan}

Peningkatan Kejadian kesakitan dan kematian akibat Penyakit Tidak Menular (PTM) menjadi ancaman serius kesehatan masyarakat karena menambah beban ekonomi dan sosial bagi masyarakat. ${ }^{[5]}$ Pencegahan dan pengendalian PTM merupakan salah satu target SDG's tahun 2030 sehingga menjadi prioritas seyiap negara. Data WHO menyatakan penyakit tidak menular merupakan penyebab kematian hampir $75 \%$ di dunia dan $80 \%$ terjadi di negara berkembang (WHO, 2018). Di Indonesia 100 penderita PTM sebanyak 70 orang tidak menyadari dirinya mengidap PTM, sehingga terlambat dalam mendapatkan penanganan yang mengakibatkan terjadinya komplikasi, kecacatan bahkan kematian. ${ }^{[1]}$

Indonesia berkomitmen untuk menurunkan angka morbiditas dan mortalitas PTM yang telah tercantum di RPJM 2015-2019, tetapi masih terdapat tantangan tantangan diantaranya belum adanya dukungan politis untuk program PTM, perilaku tidak sehat di masyarakat masih memprihatinkan, pelayanan kesehatan untuk PTM belum maksimal, masih kurangnya ketersediaan data manajemen program yag bermutu sebagai dari masih lemahnya survelens ${ }^{[2]}$

Pengendalian faktor risiko PTM dapat dilakukan oleh masyarakat sendiri melalui kegiatan Posbindu PTM (Pos Pembinaan Terpadu) dengan biaya yang terjangkau. Posbindu PTM merupakan wujud peran serta masyarakat dalam kegiatan deteksi dini, monitoring dan tindak lanjut dini faktor risiko PTM secara mandiri dan berkesinambungan. Posbindu PTM menjadi salah satu nemtuk upaya kesehatan masyarakat atau UKM yang selanjutnya berkembang menjadi upaya kesehatan bersumber daya masyarakat (UKBM) dalam pengendalian faktor risiko PTM dibawah binaan Puskesmas. ${ }^{[3]}$

Pelaksanaan Posbindu pada hampir seluruh wilayah Banyumas masih menghadapi berbagai masalah. Masalah-masalah tersebut, diantaranya yaitu: tidak adanya penyuluhan kesehatan, kurangnya pengetahuan dan keterampilan kader, kurangnya dukungan masyarakat, dan rendahnya kunjungan lansia/ kelompok sasaran. Perlu keterlibatan organisasi-organisasi yang memiliki kemampuan/potensi besar untuk dapat berkontribusi banyak terhadap program Posbindu. ${ }^{[4]}$ Menunggu pengambil keputusan dan kebijakan merevatilisasi posbindu, mengadakan pelatihan kader Posbindu, sebagai institusi kesehatan dapat berkontribusi dalam masalah posbindu, diantaranya mengadakan penyuluhan kesehatan kepada masyarakat sasaran PTM pada umumnya dan lansia dan keluarganya pada khususnya tentang PTM serta upaya deteksi dini, pengenalan faktor resiko PTM dan pengendaliaannya secara terintegrasi dengan kegiatan masyarakat yang sudah aktif seperti majelis taklim atau kegiatan pada kelompok khusus seperti di kelompok organisasi otonomi seperti Asyiyah.

Anggota ranting Asyiyah Pamijen merupakan kelompok wanita usia subur diatas 30 tahun dan para ibu lanjut usia (Lansia), dimana kelompok tersebut merupakan kelompok sasaran utama dari Posbindu PTM dari Puskesmas Sokaraja. Posbindu di desa Pamijen dilaksanakan dengan terintegrasi kegiatan posyandu balita dimana kegiatannya masih terbatas dengan hanya pemantauan tekanan darah dan pengobatan penyakit ringan, sedangkan kegiatan penyuluhan dari 
petugas kesehatan masih jarang dilaksanakan. Kondisi tersebut yang menjadikan ibu-ibu ranting asyiyah Pamijen belum tergerak untuk mengikuti Posbindu.Selain itu kondisi dari kader Posbindu yang belum siap dan belum terampil.

Survey yang pernah dikaji oleh tim melalui FGD menunjukkan bahwa mitra perlu mendapatkan penyuluhan dan konseling yang ditujukan untuk membantu mitra menemukan masalah yang berkaitan dengan faktor risiko yang dimiliki mitra dan mencari jalan keluar untuk mengendalikan faktor risiko yang dimilikinya.

Dengan meningkatnya pemahaman terhadap PTM maka masyarakat sasaran akan tergerak untuk memanfaatkan posbindu.

\section{Metode}

Metode penyelesaian maslaah yang dilaksanakan pada pengabdian masyarakat ini adalah dengan memberikan KIE (Komunikasi, Informasi dan Edukasi) berupa materi tentang Penyakit Tidak Menular (PTM) dan faktor resiko dan upaya pengendalian faktor resiko PTM. Sedangkan pelatihan dalam mengenali faktor resiko PTM dan upaya pengendaliannya, dengan simulasi kasus. Mitra dibagi menjadi kelompok kecil kemudian berlatih bersama cara berlatih menggunakan timbangan, mengukur tekanan darah, mengukur ia dan ingkar perut serta cara mensosialisasikan informasi upaya mengendalikan faktor resiko PTM pada lingkungan sekitar pamijen, kemudian mitra menjadi tutor untuk kelompok mitra akan didampingi untuk selanjutnya para mitra ini dapat menjadi tutor yang mampu memberikan informasi tentang PTM dilingkungannya

\section{Hasil dan Pembahasan}

Desa Pamijen terletak di wilayah kecamatan Sokaraja kabupaten Banyumas, terdiri dari 2 kadus, 4 RW dan 22 RT. Jumlah penduduk 3594 jiwa terdiri dari perempuan 1767 jiwa dan 1827 jiwa.

Kader Nasyiyatul Aisyiyah merupakan organisasi milik Muhammadiyah yang terdapat di desa Pamijen. Ibm ini bekerjasama dengan Nasyiyatul Aisyiyah sebagai mitra. Pemberdayaan kader Nasyiyatul Aisyiyah dalam Ibm ini diharapkan dapat memberikan pengetahuan dan menyebarkan informasi tentang Penyakit tidak menular sehingga angka kejadian dapat ditekan.

Kegiatan dimulai dari setelah penanandatangan surat perjanjian dengan LPPM. Setelah ada kesepakatan dan surat ijin terbit, ketua dan anggota berkoordinasi untuk membuat media untuk kegiatan tersebut, berupa materi, leaflet, booklet dan ppt.

Kegiatan ini dihadiri oleh kader aisyiyah dan posyandu sebanyak 20 orang. Kegiatan dimulai dengan pre test tentang pengetahuan tentang PTM dengan hasil

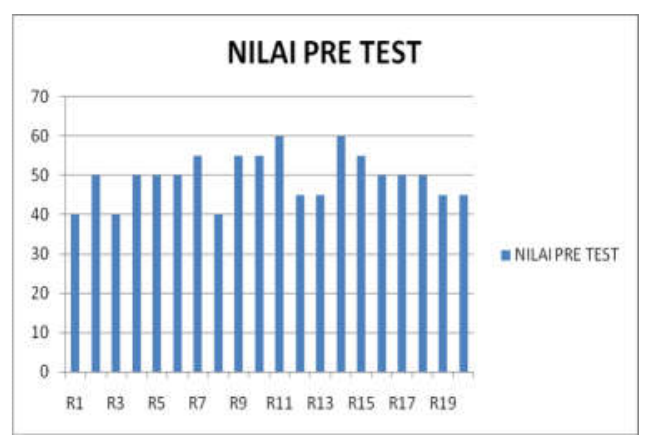

Di akhir kegiatan dilakukan post test dengan pertanyaan yang sama dengan hasil 


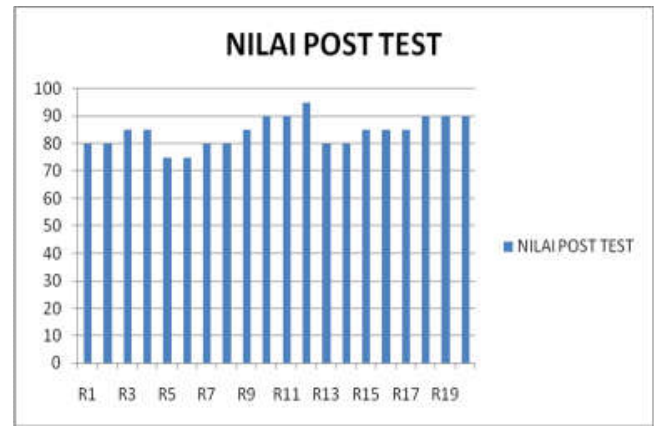

Dan hasil post test menggambarkan peningkatan pemahaman kader tentang PTM.

Pencegahan dan pengendalian faktor resiko PTM dalam program Kemenkes (2019) melipiti 4 cara, antara lain advokasi, kerjasama, bimbingan dan manajemen PTM, kedua promosi, pencegahan dan pengurangan faktor risiko PTM melalui masyarakat, ketiga penguatan kapasitas dan kompetensi layanan masyarakat serta kolaborasi sektor swasta dan profesional, dan keempat penguatan surveilans, pengawaasan dan riset PTM. Kegiatan PTM di desa Pamijen melibatkan organisasi Aisyiyah sebagai organisasi yang aktif dalam masyarakat untuk menindaklanjuti program Kemenkes sehingga program dapat berjalan sesuai yang diharapkan. Tindak lanjut dari kegiatan ini dilaksanakan pada kegiatan Posbindu di desa Pamijen yang dilaksankan ruti setiap 1 bulan sekali. Monitoring dilaksanakan pada bulan Februari minggu ketiga di Posbindu Pamijen dengan sasaran Kader yang ikut kegiatan sebelumnya.

Hambatan dari kegiatan ini adalah Kurangnya kesadaran kader pentingnya penget5ahuan PTM sehingga partisipasi dalam kegiatan ini kurang antusias..

Target luaran dari kegiatan ini adalah meningkatnya pengetahuan para mitra tentang Penyakit Tidak Menular (PTM) dan faktor resiko, upaya pengendalian faktor resiko PTM, Mitra memiliki keterampilan, sikap positif dan kemampuan mengajak serta memotivasi masyarakat lainnya untuk mengadopsi kebiasaan yang lebih sehat, mempraktekkan pengetahuan, termasuk menyebarkan informasi kepada masyarakat,adanya leaflet dan modul tentang Penyakit PTM dan faktor resiko, upaya pengendalian faktor resiko PTM yang dimanfaatkan mitra.

\section{Kesimpulan}

Ada peningkatan pengetahuan tentang PTM pada kader Aisyiyah desa Pamijen sehingga Kader Aisyiyah dapat mengenali PTM pada dirinya sendiri dan mengedukasi masyarakat untuk mengenali PTM.

\section{Daftar Pustaka}

[1] Direktorat

Pengendalian

PTM. Penyelenggaraan

Posbindu PTM. Jakarta:

Kemenkes RI, 2014.

[2] Direktorat Pengendalian

PTM. Penyakit MeTidak Menular dan Faktor Resiko. Jakarta: Kemenkes RI, 2014.

[3] Direktorat Pengendalian PTM. Upaya Pengendalian Faktor Risiko PTM. Jakarta: Kemenkes RI, 2014.

[4] Dwi Wigati Ratna Sari. Faktor-faktor yang berhubungan dan pemanfaatan posbindu penyakit tidak menular (PMT) di wilayah kerja Puskesmas Kecamatan Setiabudi Kota Jakarta Selatan, Jurnal Kebijakan Kesehatan Indonesia , Vol 7(2), pp.49-56, 2018. 
[5] Direktorat Pengendalian

PTM. Strategi pencegahan dan pengendalian PTM di Indonesia. 2019. [Online]. 5 April 2020 .

http://p2ptm.kemkes.go.id/pro fil-p2ptm/latar-

belakang/strategi-pencegahandan-pengendalian-ptm-diindonesia 